\section{Kepastian Dan Perlindungan Hukum Terhadap Pemegang Sertifikat Hak Milik Atas Tanah Berdasarkan Undang-Undang No.5 Tahun 1960 Tentang Peraturan Pokok-Pokok Agraria}

Oleh :

\section{Jawakil Butarbutar SH., M.Hum ${ }^{1}$}

\begin{abstract}
This research is related to the Basic Agrarian Law which regulates land rights including property rights by registering the rights to their land to obtain ownership rights intended for maintain legal certainty and legal protection for holders of property rights over land. For this reason, it is important to socialize the importance of registering uncertified land to become certified land for legal certainty and protection of holders of property rights on the land to avoid land problems in the community. For this reason legal certainty and protection are needed so that the status of land owned by the people is clear as well as all actions taken relating to the land such as transfer, inheritance, transfer of rights, revocation / exemption and abolition of the land rights. With the certificate, the government has a definite role to provide legal protection to the holders of property rights because the certified land has been registered at the landoffice and it becomes an obligation for the government to protect it.
\end{abstract}

Keywords: Legal Certainty and Protection, Holders of Certificates of Ownership, Agrarian Basic Law.

\begin{abstract}
Abstrak
Dalam Undang-Undang Pokok Agraria yang mengatur mengenai hak-hak atas tanah termasuk hak milik dengan mendaftarkan hak atas tanahnya untuk memperoleh hak milik yang bertujuan untuk menyelenggarakan kepastian hukum dan perlindungan hukum terhadap pemegang hak milik atas tanah.Untuk itu perlu disosialisasikan pentingnya pendaftaran tanah
\end{abstract}

\footnotetext{
${ }^{1}$ Dosen Universitas Al-Azhar Medan
}

yang belum bersertifikat menjadi tanah yang bersertifikat untuk adanya kepastian hukum serta perlindungan terhadap pemegang hak milik atas tanahtersebut agar tidak timbul permasalahan tanah dalam masyarakat. Untuk itulah maka dibutuhkan akan kepastian hukum serta perlindungannya agar jelas status tanah yang dimiliki orang tersebut maupun segala tindakan yang dilakukan yang berhubungan dengan tanah tersebut baik peralihan,pewarisan ,pemindahan hak, pencabutan/pembebasan serta hapusnya hak atas tanah tersebut. Dengan adanya sertifikat maka pemerintah memiliki peranan yang pasti untuk memberi perlindungan hukum terhadap pemegang hak milik karena tanah yang telah bersertifikat telah terdaftar di kantor pertanahan dan menjadi kewajiban bagi pemerintah untuk melindunginya.

Kata Kunci : Kepastian dan Perlindungan Hukum, Pemegang Sertifikat Hak Milik, Undang-Undang Pokok Agraria

\section{PENDAHULUAN}

\section{A. Latar Belakang}

Tanah merupakan salah satu sumber daya alam yang sangat penting di dalam kehidupan manusia. Tanah merupakan bagian dari bumi sebagai karunia dari Tuhan Yang Maha Esa, karenanya harus dilestarikan, dijaga dan dikelola dengan baik untuk generasi sekarang maupun untuk generasi mendatang.Sebagai sumber daya yang sangat menunjang kehidupan manusia, maka setiap masyarakat memiliki aturan atau norma dalam penggunaan,penguasaan, pemilikan dan pemanfaatan tanah untuk kehidupannya. Berkembangnya penduduk dan pola pikir manusia mendorong terbentuknya satu aturan di bidang pertanahan yang dapat diterima bersamasebagai landasan hukum terutama dalam pemilikan tanah. Sebagai landasan 
Media Komunikasi dan Informasi Hukum dan Masyarakat

kebijakan di bidang pertanahan,pasal 33 ayat 3 Undang-Undang Dasar 1945 yang berbunyi : "Bumi, air dan kekayaan alam yang tekandung didalamnya dikuasai oleh negara dan dipergunakan untuk sebesar-besarnya kemakmuran rakyat ${ }^{2}$.

Perwujudan dari ketentuan pasal 33 ayat 3 Undang-Undang Dasar 1945 tersebut adalah dengan lahirnya Undang-Undang Nomor 5 Tahun 1960 tentang Peraturan Dasar PokokPokok Agraria' merupakan perangkat hukum pertanahan sebagai sendi dan landasan baik baik hukum nasional maupun kepastian hukum pada politik dan sistim pertanahan nasional.

Pemberian beberapa macam hak atas tanah baik kepada perorangan atau badan hukum, juga ada kewajiban untuk mengelola tanah sesuai dengan yang dimilikinya dan kepada pemegang hak-hak tersebut dibebankan kewajiban untuk mendaftarkan hak atas tanahnya dalam rangka tercapainya kepastian hukum. Undang-Undang Pokok Agraria dengan seperangkat peraturan pelaksananya bertujuan untuk terwujudnya jaminan kepastian hukum terhadap pemilik hak-hak atas tanah di seluruh wilayah Indonesia. Jika dikaitkan dengan usahausaha pemerintah dalam rangka penataan kembali penggunaan, penguasaan dan pemilikan tanah, maka pendaftaran hak atas tanah merupakan suatu sarana penting untuk terwujudnya kepastian hukum dan sekaligus turut serta dalam penataan kembali penggunaan, penguasaan dan pemilikan tanah. Ketentuan mengenai pendaftaran tanah terdapat dalam pasal 19 ayat (1) Undang-

${ }^{2}$ Boedi Harsono, Hukum Agraria Indonesia, Sejarah Pembentukan UUPA Isi dan Pelaksanaannya, Djambatan, Jakarta, 2005, hal.3.
Undang Pokok Agraria yang berbunyi sebagai berikut:

"Untuk menjamin kepastian hukum oleh pemerintah diadakan pendaftaran tanah di seluruh wilayah Republik Indonesia menurut ketentuan-ketentuan yang diatur dengan Peraturan Pemerintah ${ }^{3}$.

Pendaftaran tanah diatur lebih lanjut dalam Peraturan Pemerintah Nomor 10 Tahun 1961 yang kemudian disempurnakan dengan Peraturan Pemerintah Nomor 24 Tahun 1997 tentang Pendaftaran Tanah. Pemerintan mengadakan pendaftaran tanah di seluruh Indonesia yang bertujuan untuk memberikan jaminan kepastian hukum hak atas tanahdan sebagai jaminan kepastian hukum tersebut dibandingkan dengan alat bukti lain seperti Akta Camat dan akta Notaris. Namun persoalan tidak sesederhana itu, dalam praktek di masyarakat pemegang sertifikat Hak Milik atas tanah tidak dilindungi seperti yang dijanjikan pemerintah maka akan ada komplikasi.

\section{B. Rumusan Masalah}

1. Bagaimana status hukum Hak Milik atas tanah dan Sertifikat Hak Milik atas tanah menurut Undang-Undang Pokok Agraria.

2. Bagaimana upaya pemerintah dalam menjamin kepastian hukum sertifikat Hak Milik atas tanah.

3. Bagaimana bentuk sumbangan pemikiran bagi masyarakat mengenai masalah kepastian dan perlindungan hukum Sertifikat Hak Milik atas tanah.

${ }^{3}$ Ibid, hal.574. 
Media Komunikasi dan Informasi Hukum dan Masyarakat

\section{Metode Penelitian}

\section{Jenis dan Sifat Penelitian}

Dalam penelitian ini penulis meneliti mengenai kepastian dan perlindungan hukum terhadap pemegang sertifikat hak milik atas tanah berdasarkan Undang-Undang No.5 Tahun 1960 Tentang Peraturan Pokok-Pokok Agraria.

Dalam studi putusan tersebut penulis menggunakan penelitian hukum secara yuridis normatif. Penelitian hukum secara normatif adalah pendekatan yang menggunakan konsepsi legis positivis. Konsep ini memandang hukum identik dengan norma-norma tertulis yang dibuat dan diundangkan oleh lembaga atau pejabat yang berwenang. Konsep ini memandang hukum sebagai suatu sistem normatif yang bersifat mandiri, tertutup atau terlepas dari kehidupan masyarakat yang nyata. $^{4}$

\section{Sumber Bahan Hukum}

Data yang dipergunakan dalam penelitian ini adalah data sekunder. Data sekunder yaitu,yang terdiri dari :

a. Bahan hukum primer

Bahan hukum primer yaitu bahan hukum yang isinya memiliki kekuatan hukum mengikat. Dalam penelitian ini antara lain, Kitab Undang-Undang Hukum Perdata dan Undang-Undang No.5 Tahun 1960 Tentang Peraturan Pokok-Pokok Agraria.

b. Bahan hukum sekunder

Bahan hukum sekunder yaitu buku, doktrin, serta bahan lain yang berkaitan dengan kepastian dan perlindungan hukum terhadap pemegang sertifikat hak milik atas tanah.

c. Bahan hukum tersier

${ }^{4}$ Ronny Hanitijo Soemitro, Teori dan Metodologi Penelitian Hukum Normatif, Ghalia Indonesia, Jakarta, 1988, hal. 13-14
Bahan hukum tersier yaitu yaitu bahan-bahan penunjang lain yang ada keterkaitan dengan pokok-pokok rumusan permasalah, memberikan kejelasan terhadap apa isi informasi, dan penjelasan terhadap bahan hukum primer dan sekunder, bukan yang ada dalam kajian bahan hukum, namum dapat dijadikan bahan analisa terhadap penerapan kebijakan hukum dilapangan, seperti kamus, ensiklopedia, buletin, majalah, artikel-artikel di internet dan bahanbahan lainnya yang sifatnya seperti karya ilmiah berkaitan dengan masalah yang akan dibahas dalam penelitian ini. ${ }^{5}$

\section{Teknik Pengumpulan Data}

a. Studi kepustakaan

Studi kepustakaan adalah pengumpulan data berupa bahan pustaka bertujuan untuk mendapatkan data sekunder yang berhubungan dengan permasalahan yang terdapat dalam penelitian ini.

b. Studi dokumen

Studi dokumen adalah pengumpulan berupa dokumen-dokumen seperti putusan pengadilan yang berkaitan dengan agraria ataupun sertifikat hak milik atas tanah dan sebagainya.

\section{PEMBAHASAN}

A. Status Hukum Hak Milik Atas Tanah Dan Sertifikat Hak Milik Atas Tanah Menurut Undang-Undang Pokok Agraria

1. Pengertian Hak Milik Atas Tanah dan Sertifikat Hak Milik Atas Tanah

Hak-hak perorangan dan Badan Hukum atas tanah memperoleh pengakuan yang kuat dalam sistim dan tata hukum Indonesia. Pasal 4

${ }^{5}$ Abdul Kadir Muhammad, Hukum dan Penelitian Hukum, Citra Aditya Bakti, Bandung, 2004, hal.151 
Media Komunikasi dan Informasi Hukum dan Masyarakat

ayat 2 Undang-Undang Pokok Agraria mengatakan bahwa:

Hak-hak atas tanah yang dimaksud dalam ayat 1 pasal ini memberi wewenang untuk mempergunakan tanah yang bersangkutan, demikian pula tubuh bumi dan air serta ruang yang ada diatasnya, sekedar di perlukan untuk kepentingan yang langsung berhubungan dengan penggunaan tanah itu dalam batasbatas menurut undang-undang ini dan peraturan-peraturan hukum lain yang lebih tinggi ${ }^{6}$.

Pengertian pada pasal 4 ayat 2 tersebut, menjelaskan hak atas tanah adalah hak atas permukaan bumi, tepatnya hanya meliputi sebagian tertentu permukaan bumi yang terbatas yang disebut dengan tanah. Azas yang hanya mengakui hak atas tanah adalah terbatas pada hak atas permukaan bumi saja disebut dengan azas pemisahan horizontal. Azas pemisahan horizontal adalah azas dimana pemilikan atas tanah dan segala sesuatu yang ada diatas tanah itu adalah terpisah. Azas pemisahan horizontal memisahkan tanah dan benda yang ada diatasnya.

Azas pemisahan horizontal adalah azas yang didasarkan pada hukum adat dan maerupakan azas yang dianut oleh UUPA.

Berbeda dengan azas yang dianut oleh UUPA, KUH Perdata menganut azas pelekatan baik yang sifatnya pelekatan horizontal maupun pelekatan vertikal, yang menyatakan bahwa benda bergerak yang tertancap atau terpaku pada benda tidak bergerak, berdasarkan azas asesi maka benda-benda yang melekat pada benda pokok, secara yuridis harus dianggap sebagai bagian yang tidak terpisahkan dari benda pokoknya. Hak-hak atas tanah yang

\footnotetext{
${ }^{6}$ A.P.Parlindungan, Komentar Atas UndangUndang Pokok Agraria, Mandar Maju, Bandung, 2008, hal.43.
}

diakui oleh UUPA salah satunya adalah hak milik. Hak milik atas tanah adalah bagian hakhak kebendaan yang dijamin dalam konstitusi. Undang-Undang DasarNegara Republik Indonesia Tahun 1945 sebagai hasil amandemen kedua pasal $28 \mathrm{~h}$ menyatakan bahwa :

Setiap orang berhak mempunyai hak pribadi dan Hak Milik Pribadi tersebut tidak boleh diambil alih secara sewenang-wenang oleh siapapun ${ }^{7}$.

Hak Milik adalah hak turun temurun, terkuat dan terpenuh yang dapat dipunyai orang atas tanah, memiliki fungsi sosial serta dapat dialihkan dan beralih. Arti Hak Milik mempunyai fungsi sosial ialah bahwa Hak Milik yang dipunyai oleh seseorang tidak boleh dipergunakan semata-mata untuk kepentingan pribadi atau perorangan, tetapi juga untuk kepentingan masyarakat banyak. Jadi Hak Milik itu harus mempunyai fungsi kemasyarakatan yang memberikan berbagai hak bagi orang lain. Hak Milik atas tanah mengandung unsur hak kebendaan dan hak perorangan. Sebagai hak kebendaan, hak milik atas tanah memiliki ciriciri bersifat absolut, jangka waktunya tidak terbatas, hak mengikuti bendanya (droit de suite) dan memberi wewenang yang luas bagi pemiliknya seperti dialihkan,dijaminkaan, disewakan atau dipergunakan sendiri. Sebagai hak perseorangan, ciri-cirinya adalah bersifat relatif, jangka waktunya terbatas, mempunyai kekuatan yang sama tidak tergantung saat kelahirannya hak tersebut, memberi wewenang terbatas pada pemiliknya.

Perolehan Hak Milik atas tanah diikuti dengan pemberian sertifikat sebagai bukti

\footnotetext{
${ }^{7}$ Perubahan kedua Undang-Undang Dasar Republik Indonesia Tahun 1945.
} 
Media Komunikasi dan Informasi Hukum dan Masyarakat

kepemilikan hak. Memperoleh sertifikat adalah hak pemegang Hak Milik atas tanah yang dijamin oleh undang -undang. Sertifikat Hak Milik merupakan suatu tanda bukti hak atas kepemilikan suatu bidang tanah yang dibukukan dan diberikan Pemerintah kepada pemegang Hak Milik untuk melindungi haknya. Sertifikat berisi salinan dari Buku Tanah dan Surat Ukur yang dijilid menjadi satu disampul yang bentuknya ditetapkan dengan undang-undang. Menurut Peraturan Pemerintah Nomor 24 Tahun 1997, sertifikat adalah satu lembar dokumen sebagai suatu tanda bukti yang memuat data fisik maupun data yuridis objek yang didaftar untuk Hak Milik atas tanah yang dibukukan dalam buku tanah.

Data fisik dan data yuridis mengandung pengertian sebagai berikut:

a. Data fisik yaitu keterangan mengenai letak, batas, dan luas bidang tanah yang didaftar termasuk keterangan mengenai adanya bangunan atau bagian bangunan ndiatasnya.

b. Data Yuridis yaitu keterangan mengenai status hukum bidang ntanah yang di daftar pemegang Hak Milik atas tanah dan hak pihak lain serta beban-beban lain yang membebaninya.

\section{Cara Peralihan Hak Milik Atas Tanah}

Hak Milik atas tanah mengandung unsur hak kebendaan dan hak perorangan. Sebagai hak kebendaan, hak atas tanah memiliki ciri-ciri bersifat absolut, jangka waktunya tidak terbatas, hak mengikuti bendanya (droit de suite), dan memberi wewenang yang luas bagi pemiliknya seperti dialihkan, dijaminkan, disewakan atau dipergunakan sendiri. Sebagai hakm perorangan, cir-cirinya adalah bersifat relatif, jangka waktunya terbatas, mempunyai kekuatan yang sama tidak tergantung saat kelahirannya hak tersebut, memberi wewenang terbatas pada pemiliknya. Dalam UUPA dikenal dua cara peralihan Hak Milik Atas tanah yaitu dengan cara pewarisan (berdasarkan undang-undang dan berdasarkan wasiat) dan pemindahan hak.

\section{Peralihan Hak Milik atas tanah karena Pewarisan}

Peralihan Hak Milik atas tanah dapat terjadi karena pewarisan (berdasarkan undangundang atau berdasarkan wasiat). Menurut hukum perdata jika pemegang suatu Hak Milik atas tanah meninggal dunia, hak tersebut karena hukum beralih kepada ahli warisnya, inilah yang disebut dengan pewarisan berdasarkan undang-undang (ab intestato). Peralihan tersebut kepada para ahli warisnya yaitu siapa-siapa yang menjadi ahli waris, berapa bagian masing-masing dan bagaimana cara pembagiannya diatur oleh hukum waris almarhum pemegang hak yang bersangkutan, bukan oleh hukum tanah.

Hukum Tanah memberikan ketentuan mengenai penguasaan tanah yang berasal dari warisan dan hal-hal mengenai pemberian surat tanda bukti pemilikannya oleh para ahli waris. Dalam pasal 20 Peraturan Pemerintah Nomor 10 Tahun 1961 tentang Pelaksanaan Pendaftaran Tanah, menyatakan dalam waktu 6 bulan sejak meninggalnya pemegang hak, para ahli war isnya wajib meminta pendaftaran peralihan hak dalam rangka memberikan perlindungan hukum kepada ahli waris.

Hukum juga mengenal satu lagi cara peralihan hak atas tanah dengan pewarisan yaitu peralihan berdasarkan surat wasiat (testamenter) yang memuat pernyataan dari pemegang Hak Milik tentang apa yang 
Media Komunikasi dan Informasi Hukum dan Masyarakat

dikehendakinya terhadap hak tersebut setelah dia meninggal dunia. Pendaftaran peralihan hak karena pewarisan, mengenai hak bidang tanah yang sudah didaftar wajib diserahkan oleh yang menerima hak sebagai warisan kepada Kepala Kantor Pertanahan ,sertifikat yang bersangkutan, surat kematian orang yang namanya tercatat sebagai pemegang haknya dan surat tanda bukti sebagai ahli waris. Jika penerima warisan terdiri dari satu orang pendaftaran peralihan haknya dilakukan kepada orang tersebut berdasarkan surat tanda bukti sebagai ahli waris yang bersangkutan. Apabila penerima waris lebih dari satu orang dan waktu peralihan hak tersebut didaftarkan disertai dengan akta pembagian waris yang memuat keterangan bahwa hak milik atas tanah jatuh kepada seorang penerima warisan tertentu, pendaftaran peralihan haknya dilakukan langsung kepada penerima warisan yang bersangkutan berdasarkan surat tanda bukti sebagai ahli waris dan akta pembagian waris tersebut tanpa alat bukti peralihan hak lain, misalnya akta PPAT. Akta pembagian waris tersebut dapat dibuat dalam bentuk akta dibawah tangan oleh semua ahli waris dengan kesaksian oleh dua orang saksi atau dengan akta notaris.

Berbeda dengan beralihnya Hak Milik atas tanah karena pewarisan yang terjadi karena hukum dengan meninggalnya pemegang hak, dalam perbuatan hukum pemindahan hak, hak tanah yang bersangkutan sengaja dialihkan kepada pihak lain. Bentuk pemindahan haknya bisa :
a. Jual beli
b. Tukar menukar
c. Hibah
d. Pemberian menurut adat
e. Pemasukan dalam perusahaan

f. Hibah wasiat atau "legaat"

Perbuatan-perbuatan itu dilakukan pada waktu pemegang haknya masih hidup dan merupakan perbuatan hukum pemindahan hak yang bersifat tunai, kecuali hibah wasiat. Artinya bahwa dengan dilakukannya perbuatan hukum yang bersangkutan tersebut, hak milik atas tanah yang bersangkutan berpindah kepada pihak lain yaitu penerima hak. Dalam hibah wasiat hak milik atas tanah yang bersangkutan beralih kepada penerima wasiat pada saat pemegang haknya meninggal dunia. Jual beli, tukar menukar, hibah, pemberian menurut adat dan pemasukan dalam perusahaan, demikian juga dalam pelaksanaan hibah wasiat dilakukan oleh para pihak dihadapan Pejabat Pembuat Akta Tanah (PPAT).

Ketika dibuatnya perbuatan hukum yang bersangkutan dihadapan pejabat yang berwenang dipatuhilah syarat terang (bukan perbuatan hukum yang gelap yang dilakukan secara sembunyi-sembunyi). Akta yang ditanda tangani para pihak menunjukkan secara nyata atau riil perbuatan hukum jual beli yang dilakukan, dengan demikian ketiga sifat jual beli yaitu tunai, terang, dan riil dipenuhi. Akta tersebut membuktikan, bahwa benar telah dilakukan perbuatan hukum yang bersangkutan, karena perbuatan hukum yang dilakukan merupakan perbuatan hukum pemindahan hak, maka akta tersebut secara implisit membuktikan bahwa penerima hak menjadi pemegang haknya yang baru, tetapi hal ini baru diketahui oleh dan karenanya juga baru mengikat para pihak dan ahli warisnya karena administrasi PPAT sifatnya tertutup bagi umum.

\section{Pembebasan dan Pencabutan Hak Milik Atas Tanah \\ Mengenai hak kepemilikan atas tanah sifatnya tidak mutlak, artinya jika kepentingan}


Media Komunikasi dan Informasi Hukum dan Masyarakat

negara atau kepentingan umum menghendaki, hak kepemibebaskan dengan pemilikan perorangan atau badan usaha atas sebidang tanah dapat dibebaskan dengan pemberian ganti rugi.

Pasal 18 UUPA berbunyi: "Untuk kepentingan umum, termasuk kepentingan bangsa dan negara serta kepentingan bersama dari rakyat, hak-hak atas tanah dapat dicabut dengan memberi ganti kerugian yang layak dan menurut cara yang diatur dengan UndangUndang".

Kepentingan umum ini termasuk kepentingan Negara dan kepentingan bersama rakyat sebagai syarat pertama dan utama dalam pencabutan hak ini untuk dapat diperlakukan pasal 6 UUPA, sehinbgga tidak mungkin pembebasan untuk perorangan. Kepentingan swasta yang berdampak kepada kepentingan umum, atau kepentingan negara dan kepentingan bersama dapat juga dikatagorekan memenuhi syarat pertama ini. Pengertian layak juga harus yang objektif dan harga dasar adalah berdasarkan penetapan pemerintah daerah berdasarkan minimal Nilai Jual Objek Pajak (NJOP).

Sebagai pelaksanaan pasal 18 UUPA tata cara pelepasan dan penyerahan hak tesebut diatur dalam Keputusan Presiden Nomor 55 Tahun 1993 tentang Pengadaan Tanah bagi Pelaksanaan Pembangunan untuk Kepentingan Umum. Dalam pasal 5 Kepres ini disebutkan sejumlah ketentuan-ketentuan yang dianggap sebagai kepentingan umum :
1. Jalan umum
2. Saluran pembuangan air
3. Waduk
4. rumah sakit umum

5. pelabuhan atau bandar udara

6. tempat peribadatan

7. tempat pendidikan atau sekolah

8. pasar umum

9. tempat pemekaman umum

10. fasilitas keselamatan umum

11. pos dan telekomunikasi

12. sarana olah raga

13. stasiun penyiaran radio

14. televisi

15. kantor pemerintah dan

16. fasilitas angkatan bersenjata

Pembebasan ialah melepaskan

hubungan hukum yang semula terdapat pada pemegang hak dengan diberi ganti rugi. Perbedaan mendasar antara pembebasan hak dengan pencabutan hak adalah pada pelaksanaannya, dalam pembebasan hak kewenangan terlaksananya melalui proses musyawarah dan mufakat, dengan kata lain terjadi karena adanya kesepakatan bersama dan sukarela yang dicapai melalui musyawarah sedangkan dalam pencabutan hak pihak yang mempunyai tanah berhadapan bukan dengan sesama pihak yang kedudukan hukumnya sederaja melainkan berhadapan dengan Penguasa yaitu Presiden Republik Indonesia yang dilakukan dengan Surat Keputusan Presiden. Pencabutan hak menyatakan bahwa yang haknya dicabut itu tidak dapat menyatakan tidak bersedia haknya dicabut dan kalaupun dia diberikan hak untuk banding maka bandingnya kepada Pengadilan Tinggi hanya mengenai jumlah ganti rugi yang ditawarkan Pemerintah, yang bersangkutan tidak dapat meminta Pemerintah membuktikan tentang adanya unsur kepentingan umum dalam pencabutan hak dimaksud, artinya dalam pelaksanaan pembangunan untuk kepentingan umum ini berdasarkan kewenangannya Pemerintah 
Media Komunikasi dan Informasi Hukum dan Masyarakat

melakukan upaya paksa walupun dengan unsur itikad yang diwujudkan dalam bentuk ganti rugi yang layak.

\section{Kepastian dan Perlindungan Hukum Pemegang Setifikat Hak Milik atas Tanah}

Seperti diuraikan diatas bahwa sertifikat Hak Milik atas tanah merupakan suatu tanda bukti hak atas kepemilikan suatu bidang tanah yang dibukukan dan diberikan Pemerintah kepada pemegang Hak Milik untuk melindungi haknya. Sebagai kelanjutan dari pemberian perlindungan hukum kepada para pemegang sertifikat hak milik atas tanah dinyatakan dalam pasal 32 ayat (2):

Ketika atas suatu bidang tanah sudah diterbitkan sertifikat secara sah atas nama orang atau badan hukum yang memperoleh tanah tersebut dengan itikad baik dan secara myata menguasainya, maka pihak yang merasa mempunyai hak atas tanah ini tidak dapat lagi menuntut pelaksanaan hak tersebut apabila dalam waktu5 (lima) tahun sejak diterbitkannya sertifikatitu tidak mengajukan keberatan secara tertulis kepada pemegang sertifikat danKepala Kantor Pertanahan yang bersangkutan ataupun tidak mengajukan gugatan di Pengadilan mengenai penguasaan tanah dan penerbitan sertifikat tersebut ${ }^{8}$.

Adanya pernyataan tersebut maka Sertifikat merupakan alat pembuktian yang kuat dan tujuan pendaftaran tanah yang diselenggarakan dalam rangka memberikan jaminan kepastian hukum dibidang pertanahan, sungguhpun sistim publikasi yang digunakan adalah sistim negatif.

\footnotetext{
8 Bahtiar Efendi, Pendaftaran Tanah di Indonesia dan Peraturan Pelaksananya, PT. Alumni, Bandung, 1983, hal. 33 .
}

Kelemahan sistim negatif adalah ,bahwa pihak yang namanya tercantum sebagai pemegang hak dalam buku tanah dan sertifikat selalu menghadapi kemungkinan gugatan dari pihak lain yang merasa mempunyai tanah itu.Untuk mengatasi kelemahan sistim negatif ini dalam pendaftaran tanah hukum adat sebagai sumber hukum tanah nasional menggunakan lembaga rechtverwerking (lembaga yang berwenang mengatur sebab pemegang hak atas tanah bisa kehilangan haknya). Dalam Hukum Adat bahwa jika seseorang selama sekian waktu membiarkan tanahnya tidak dikerjakan kemudian tanah itu dikerjakan orang lain yang memperolehnya dengan itikad baik maka dianggap telah melepaskan haknya atas bidang tanah yang bersangkutan dan karenanya hilanglah haknya untuk menuntut kembali tanah tersebut.

\section{Tanggung Jawab Badan Pertanahan terhadap Penerbitan Sertifikat Hak Milik yang Bermasalah \\ Di bidang pertanahan jaminan kepastian} hukum merupakan salah satu tugas yang diemban oleh Pemerintah, untuk dapat melaksanakan tugasnya Pemerintah membentuk Badan Pertanahan Nasional (BPN) sebagai instansi yang khusus menangani pelaksanaan dalam pemberian jaminan tersebut termasuk dalam penerbitan dan pemeliharaanb sertifikat sebagai tanda bukti kepemilikan hak atas tanah.

Pendaftaran yang secara sistematik dilakukan sebelum penerbitan sertifikat oleh Kepala Kantor Pertanahan, dalam pelaksanaannya dibantu oleh Panitia Ajudikasi. Ajudikasi adalah kegiatan yang dilaksanakan dalam rangka proses pendaftaran tanah untuk pertama kali, meliputi pengumpulan dan 
Media Komunikasi dan Informasi Hukum dan Masyarakat

pemeriksaan kebenaran data fisik dan data yuridis mengenai objek pendaftaran tanah untuk kepentingan keperluan pendaftarannya.Panitia Ajudikasi dibentuk oleh Menteri, susunan Panitianyasebagai dimaksud pada pasal 8 ayat

(2) Peraturan Pemerintah Nomor 24 Tahun 1997 tentang Pendaftaran Tanah terdiri dari :

(1) Seorang Ketua Panitia, merangkap anggota yang dijabat oleh seorang pegawai Badan Pertanahan Nasional;

(2) Beberapa anggota yang terdiri dari:

a. seorang pegawai Badan Pertanahan Nasional yang mempunyai kemampuan pengetahuan di bidang pendaftaran tanah;

b. seorang pegawai Badan Pertanahan Nasional yang mempunyai kemampuan pengetahuan di bidang hak-hak atas tanah;

c. Kepala Desa/Kelurahan yang bersangkutan dan atau seorang pamong Desa/Kelurahan yang ditunjuknya.

Sebelum penerbitan sertifikat, peta bidang-bidang tanah yang bersangkutan sebagai hasil pengukuran yang dilakukan Panitia Ajudikasi diumumkan selama 30 (tiga puluh) hari dalam pendaftaran tanah secara sistematis atau 60 (enam puluh) hari dalam pendaftaran tanah secara sporadis, untuk memberi kesempatan kepada pihak yang berkepentingan mengajukan keberatan. Pengumuman dilakukan di Kantor Kepala Desa/Kelurahan letak tanah yang bersangkutan dalam pendaftaran tanah secara sitematis atau di Kantor Petanahan dan Kantor Kepala Desa/Kelurahan letak tanah yang bersangkutan dalam pendaftaran tanah secara seporadis individual, pengumuman dapat dilakukan melalui media massa/Keseluruhan dari kegiatan tersebut merupakan bentuk tanggung jawab dari BPN sebagai institusi penjamin kepastian hukum di bidang pertanahan untuk memberikan kebenaran atas data yang disajikan. Apabila terjadi masalah terhadap sertifikat yang diberikan oleh BPN, dan dapat dibuktikan bahwa masalah tersebut terjadi sebagai akibat dari tidak dilaksanakannya salah satu prosedur dalam penerbitan sertifikat maka pertanggung jawaban atas masalah tersebut dapat dibebankan kepada BPN atau Kantor Pertanahan sebagai instansi vertikal dari BPN.

\section{B. Upaya Pemerintah Dalam Menjamin Kepastian Hukum Sertifikat Hak Milik Atas Tanah}

\section{Pendaftaran Tanah}

Secara histori pendaftaran tanah yang dikenal di dunia ini berasal dari Mesir kuno ,ketika raja Firaun memerintahkan pegawai kerajaannya untuk mengembalikan patok-patok batas tanah pertanian rakyat yang hilang akibat meluapnya sungai Nil. Dari segi istilah, ditemukan istilah pendaftaran tanah dalam bahasa latin disebut "Capitastrum", di Jerman dan Italia disebut "Catastro", di Perancis disebut "kadastrale" atau "kadaster". Maksud dari Capitastrum atau kadaster dari segi bahasa adalah suatu register atau capita atau unit yang diperbuat untuk pajak tanah Romawi, yang berarti suatu istilah teknis untuk record (rekaman) yang menunjuk kepada luas, nilai dan kepemilikan atas sebidang tanah.

Di Indonesia pendaftaran tanah masi8h baru atau boleh disebutkan tidak tumbuh bersama adanya Hak Milik maasyarakatdi negara ini. Dalam catatan sejarah pendaftaran tanah di Indonesia ada sejak Ordonansi Balik Nama yang mulai di berlakukan sejak tanggal 2 April 1834. 
Media Komunikasi dan Informasi Hukum dan Masyarakat

\section{Tujuan Pendaftaran Tanah}

Berdasarkan pasal 3 PP 24 Tahun 1997

tentang Pendaftaran Tanah, maka dapatdirincikan tujuan dari pendaftaran tanah adalah :

a. Untuk memberikan kepastian hukum dsan perlindungan hukum kepada pemegang hak atas suatu bidang tanah, satuan rumah susun, dan hak-hak lain yang terdaftar agar dengan mudah dapat membuktikan dirinya sebagai pemegang hak yang bersangkutan, untuk itu kepada pemegang hak Pemerintah agar dengan mudah dapat memperoleh data yang diperlukan dalam mengadakan perbuatan hukum mengenai bidang-bidang tanah yang sudah terdaftar. Penyajian data tersebut diselenggarakan oleh Kantor Pertanahan.

b. Tertib administrasi pertanahan, terselenggaranya pendaftaran tanah dengan baik merupakan perwujudan tertib administrasi di bidang pertanahan. Untuk mencapai tertib administrasi tersebut setiap bidang tanah dan satuan rumah susun termasuk peralihan, pembebanan dan hapusnya wajib didaftar.

\section{Upaya Hukum Pemegang Sertifikat atas Tanah Apabila Terjadi Masalah}

Ketika terjadi masalah terhadap sertifikat Hak Milik atas tanah yang diterbitkan oleh Badan Pertanahan Nasional, Pemerintah memberikan kesempatan bagi para pihak yang merasa haknya dirugikan oleh pihak lain untuk dapat membuktikan adanya hak yang dikuasai berdasarkan itikat baik tersebut, dengan melakukan beberapa upaya hukum berikut ini:

a. Pemegang Sertifikat Hak atas tanah yan $g$ merasa keberatan atau merasa dirugikan aatas adanya Putusan terhadap hak yang bersangkutan, dapat melakukan upaya hukum Perlawanan (verzet) atas Putusan tersebut.

b. Melakukan gugatan melalui Pengadilan Tata Usaha Negara terhadap Badan Pertanahan Nasional.

Badan Pertanahan Nasional adalah instansi yan g ditunjuk oleh Pemerintah untuk melaksanakan kegiatan pendaftaran tanah dalam rangka menjamin kepastian hukum di bidang pertanahan termasuk dalam penerbitan tanda buktinya dan pemeliharaannya. Kegiatan pendaftaran tanah merupakan kegiatan tata usaha negara, karenanya instansi yang bertugas dibidang pelaksanaan pendaftaran tanah yang merupakan kegiatan dibidang Eksekutif/Tata Usaha Negara dinyatakan sebagai instansi Tata Usaha Negara.

Sertifikat adalah tanda bukti atas kepemilikan hak atas tanahyang diterbitkan oleh Badan Pertanahan Nasional, karenanya sertifikat dinyatakan sebagai Surat Keputusan Tata Usaha Negara. Sebagai surat keputusan , sertifikat dinyatakan sebagai alat pembuktian yang kuat, tetapi tidak berlaku mutlak artinya apabila ada pihak yang dapat membuktikan sebaliknya maka sertifikat tersebut dapat dibatalkan .BPN sebagai satu-satunya instansi yang bewrwenang menerbitkan surat Keputusan Tata Usaha Negara tersebut harus dapat dimintai pertanggung jawaban secara perdata dan diminta ganti rugi atas sertifikat yang dalam penerbitannya ternyata bermasalah dan permasalahan tersebut dapat dibuktikan berasal dari adanya kesalahan penelitian dan prosedural yang dilakukan oleh pegawai Badan Pertanahan Nasional 
Media Komunikasi dan Informasi Hukum dan Masyarakat

\section{Kesimpulan}

1. Hak milik atas tanah adalah sebagai bagian dari hak-hak kebendaan yang dijamin keberadaannya oleh konstitusiyan g di atur dalam pasal 28 h UUD 1945 yang telah di amandemen bahwa setiap orang berhak mempunyai Hak Milik pribadi dan tidak boleh diambil sewenang-wenang oleh siapapun. Hak milik adalh hak yang terkuat, turun temurun dan terpenuh yang dipunyai seseorang dan berazaskan fungsi sosial. Dalam rangka kepastian hukum Pemerintah mengadakan pendaftaran tanah yang bertujuan untuk menciptakan jaminan kepastian hukum atas pemilikan tanah.

2. Pemerintah memberi kepastian hukum kepada pihak yang dengan itikad baik menguasai sebidang tanah dan didaftar sebagai pemegang hak dalam buku tanah dengan sertifikat sebagai tanda buktinya yang menurut Undang-Undang Pokok Agraria berlaku sebagai alat pembuktian yang kuat.

\section{Daftar Pustaka}

Abdul Kadir Muhammad, Hukum dan Penelitian Hukum, Citra Aditya Bakti, Bandung, 2004.

Boedi Harsono, Hukum Agraria,Sejarah Pembentukan UUPA Isi dan Pelaksanaannya, Djambatan, Jakarta, 2005.

Effendi Bachtiar, Pendaftaran Tanah di Indonesia dan Peraturan Pelaksananya, PT.Alumni, Bandung, 1983,

Gautama Sudargo, Tafsiran Undang-Undang Pokok Agraria, PT Citra Aditya Bakti, Bandung, 1990.

Parlindungan A.P, Komentar Atas UndangUndang Pokok Agraria, Mandar Maju Bandung, 1991.

Konversi Hak-Hak Atas Tanah, Mandar Maju, Bandung, 1990.

Ronny Hanitijo Soemitro, Teori dan Metodologi Penelitian Hukum Normatif, Ghalia Indonesia, Jakarta, 1988.

Soerodjo, Irawan, Kepastian Hukum Hak Atas Tanah di Indonesia, Arloka, Surabaya, 2003. 